\title{
Periovulatory Endocrinology and Oocyte Maturation in Unmated Mature Blue Fox Vixens (Alopex lagopus)
}

\author{
By W. Farstad, M. Mondain-Monval, P. Hyttel, A. J. Smith and D. Markeng \\ Department of Reproduction and Forensic Medicine, Norwegian College of Veterinary Medicine, Oslo, \\ The Foundation for Hormonal Research, Fresnes, France, \\ Department of Anatomy, Royal Veterinary and Agricultural University, Copenhagen, Denmark \\ and The Research Farm for Furbearing Animals, Heggedal, Norway.
}

Farstad, W., M. Mondain-Monval, P. Hyttel, A. J. Smith and D. Markeng: Periovulatory endocrinology and oocyte maturation in unmated mature blue fox vixens (Alopex lagopus). Acta vet. scand. 1989, 30, 313-319. - Nine of 10 mature blue fox vixens (Alopex lagopus) in spontaneous oestrus ovulated approximately 2 days after the preovulatory increase in luteinizing hormone (LH). Plasma concentrations of follicle-stimulating hormone and progesterone increased simultaneously with the LH peak, whereas oestradiol-17 $\beta$ peaked 1 day previously. In the tenth vixen, an LH peak was not observed, and neither visible follicles nor corpora lutea were found in the ovaries 6 days after peak vaginal electrical resistance.

Eggs were ovulated as primary oocytes, but oocyte maturation was initiated within the day of ovulation ( 2 days after the LH peak). Within the next 2 days (3-4 days after the LH peak) the first polar body was extruded, and the cumulus mass was completely dissociated from the zona pellucida.

The interval between the preovulatory LH peak and initiation of the final oocyte maturation is thus considerably longer in the blue fox than for example in the cow (48-72 h compared with 9-12 h). This suggests that the relationship between these two events is somewhat different in the blue fox.

endocrinology; ovulation; oocyte maturation;

\section{Introduction}

Mammalian oocytes are not capable of undergoing fertilization and embryonic development until the first meiotic division has been completed. In most mammals, the first meiotic division takes place during the last few hours before ovulation (Staigmiller \& Moor 1984). In the monoestrous domestic dog and silver fox, however, this division is not completed until 3 and 1 days after ovulation, respectively. Until then the oocytes cannot be fertilized (Holst \& Phemister 1971, Pearson \& Enders 1943).

The aim of the present study was to examine whether the final oocyte maturation in blue fox vixens follows the pattern described for other Canidae, and to relate some of the features of oocyte maturation to endocrine changes and clinical parameters during oestrus.

\section{Materials and methods}

Ten mature blue fox vixens (average age: 5 years old) in natural oestrus were used. Blood samples were collected weekly for hormonal assays from late anoestrus until pro-oestrus, when daily sampling was initiated. The vixens were tested for behavioural oestrus by males. Vaginal electrical resistance was measured from pro-oestrus and 
through oestrus, using the technique described by Moller et al. (1984). The vixens were euthanised at varying intervals after peak vaginal electrical resistance $(E R+0): E R+1$ day $(\mathrm{n}=1), \mathrm{ER}+2$ days $(\mathrm{n}=1), \mathrm{ER}+3$ days $(n=2), E R+4$ days $(n=3), E R+5$ days $(n=$ $2)$ and ER +6 days $(n=1)$. None of the vixens were mated. Ovaries and reproductive tracts were collected at euthanasia.

\section{Hormone assays}

Luteinizing hormone (LH). Plasma LH concentrations were measured by a modification of the double-antibody radioimmunoassay previously described (Mondain-Monval et al. 1984, Moller et al. 1984). The inter-assay and intra-assay coefficients of variation were 4.9 and $2.0 \%$, respectively $(\mathrm{n}=$ 10 ), at a level of $3.2 \mathrm{ng} / \mathrm{ml}$. Minimum assay sensitivity was $0.5 \mathrm{ng} / \mathrm{ml}$.

Follicle-stimulating hormone. FSH concentrations were determined by a heterologous double-antibody radioimmunoassay described for the fox by Mondain-Monval et al. (1988). The inter-assay and intra-assay coefficients of variation were $7.2 \%$ and $5.5 \%$, respectively $(n=7)$, at a level of 130 $\mathrm{ng} / \mathrm{ml}$. Minimum assay sensitivity was 20 $\mathrm{ng} / \mathrm{ml}$.

Steroids. Plasma concentrations of oestradiol $17 \beta$ and progesterone were determined by the radioimmunoassays previously described by Mondain-Monval et al. (1977) with the modifications of Moller et al. (1984). The inter-assay and Intra-assay coefficients of variation were $6.9 \%(n=7)$ and $6.3 \%(\mathrm{n}=13)$, respectively, for progesterone, and $10.0 \%(n=10)$ and $5.3 \%(n=10)$ for oestradiol-17 $\beta$. Minimum assay sensitivity was $0.16 \mathrm{nmol} / 1$ for progesterone and $14.1 \mathrm{pmol} / \mathrm{l}$ for oestradiol-17 $\beta$.

\section{Statistical analysis}

All values are reported as mean \pm SD except in Fig. 1 where mean \pm SEM is used.

\section{Oocyte treatment}

Oocytes were collected from preovulatory follicles by aspiration, and/or from oviducts by flushing with $0.1 \mathrm{~mol} / 1$ phosphate buffer. A total of 85 fresh oocytes were isolated. Oocyte morphology was evaluated by use of a stereomicroscope at $100 \times$ magnification. Oocyte features such as the degree of cumulus investment and expansion and, if possible, presence of the first polar body, were recorded. After evaluation, the specimens were fixed in $0.1 \mathrm{~mol} / 1$ phosphate buffer with $3 \%$ glutaraldehyde for $1 \mathrm{~h}$, washed once in fresh phosphate buffer and aspirated into prelabelled French ministraws for postage to Denmark. Upon arrival, the oocytes were processed for light- and transmission electron microscopy as described by Hyttel \& Madsen (1987).

\section{Results}

The periovulatory profiles of FSH, LH, oestradiol and progesterone are presented in Fig. 1.

In all but 1 vixen, a major preovulatory $\mathrm{LH}$ peak, and a concomitant FSH peak and increase in progesterone were detected. The durations of the $\mathrm{LH}$ peak $(22.5 \pm 2.9 \mathrm{ng} / \mathrm{ml})$ and the FSH peak $(200 \pm 106 \mathrm{ng} / \mathrm{ml})$ were 1-2 days. FSH levels were high in late anoestrus, with large weekly fluctuations, peak values exceeding those of the preovulatory FSH peak (300-400 ng/ml). In pro-oestrus, FSH levels decreased to $30-40 \mathrm{ng} / \mathrm{ml}$, peaked simultaneously with the LH peak, declined on the second day of oestrus $(\mathrm{LH}+2)$ and then increased after $\mathrm{LH}+5$. The vixen in which no preovulatory LH peak was detected had high plasma FSH concentrations during the whole sampling period (February-April) and had extremely high FSH values (> $1000 \mathrm{ng} / \mathrm{ml}$ ) during pro-oestrus, in contrast to the other vixens $(40-300$ $\mathrm{ng} / \mathrm{ml})$. 

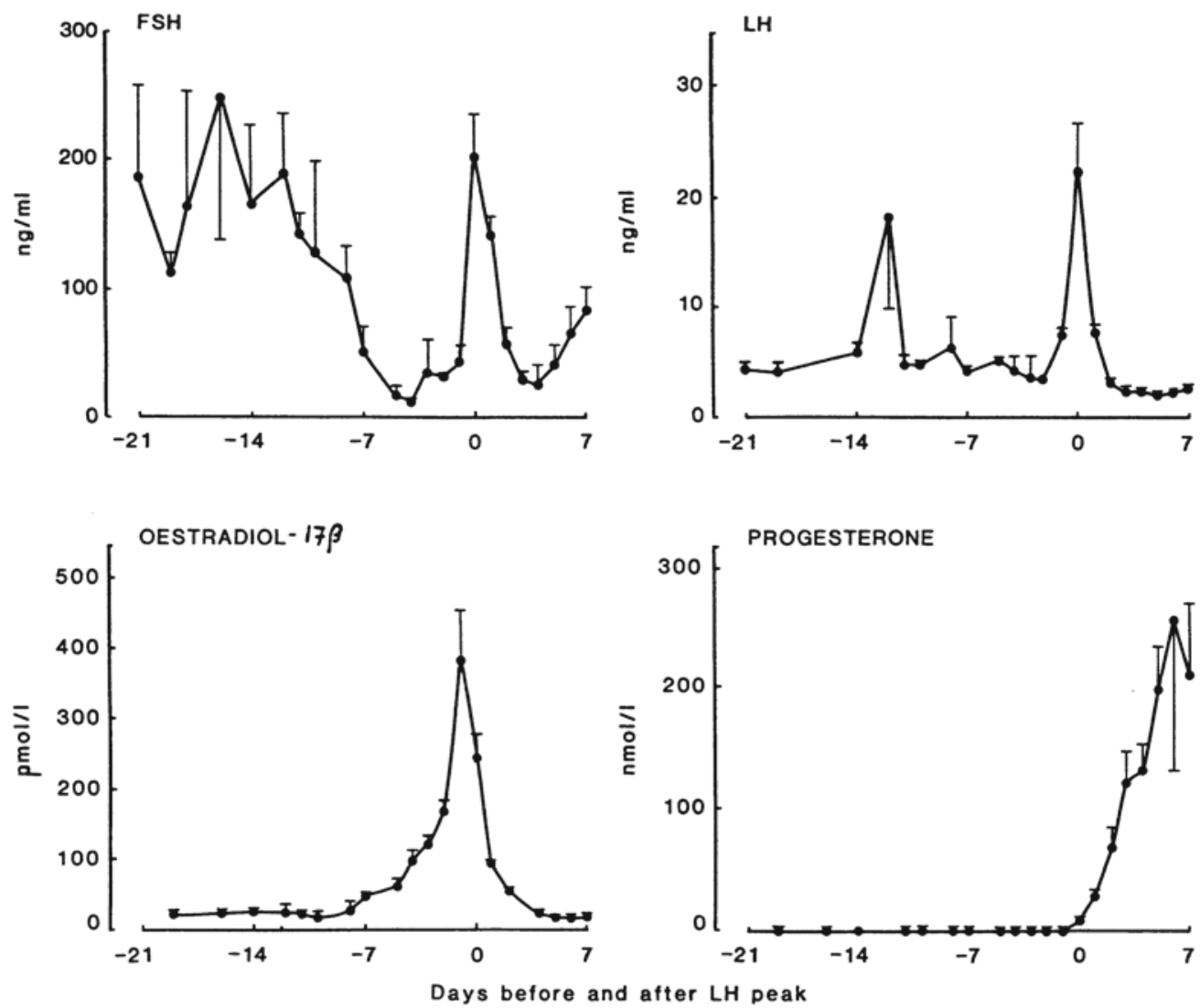

Figure 1. Mean plasma concentrations of FSH, LH, oestradiol-17 $\beta$ and progesterone in the 7 vixens that ovulated, 1 vixen with luteinized follicles and 1 vixen with preovulatory follicles. The results are synchronized to the day of the LH peak. Values are means \pm S.E.M. of 3-9 animals on each sampling date.

Oestradiol-17 $\beta$ concentrations peaked approximately 1 day before the LH peak (mean $244.5 \pm 107.2 \mathrm{pmol} / \mathrm{l}$ ).

The maximum vaginal electrical resistance occurred on average $1 / 2$ day after the $\mathrm{LH}$ peak or $11 / 2$ days after the oestradiol-17 $\beta$ peak. Most vixens came into oestrus on the day of the LH peak or the day after. Mean progesterone levels were significantly elevated above baseline levels at the time of the LH peak $(9.5 \pm 6.9 \mathrm{nmol} / \mathrm{l})$, and values above $31.4 \mathrm{nmol} / 1$ were detected at the time of ovulation (mean $70.0 \pm 38.6 \mathrm{nmol} / \mathrm{l}$ ).
The one vixen in which no preovulatory $\mathrm{LH}$ peak was found had no visible follicles or corpora lutea in the ovaries when sacrificed 6 days after peak vaginal electrical resistance $(\mathrm{ER}+6)$.

One vixen sacrificed the day after the $\mathrm{LH}$ peak $(E R+1)$ had normal preovulatory follicles and had not ovulated. Seven of 8 vixens sacrificed 2 or more days after the $\mathrm{LH}$ peak $(\mathrm{SE}+2$ to $\mathrm{ER}+5)$ had started or completed ovulation, whereas 1 vixen had only luteinized follicles in the ovaries when sacrificed 4 days after the LH peak $(E R+2)$. 


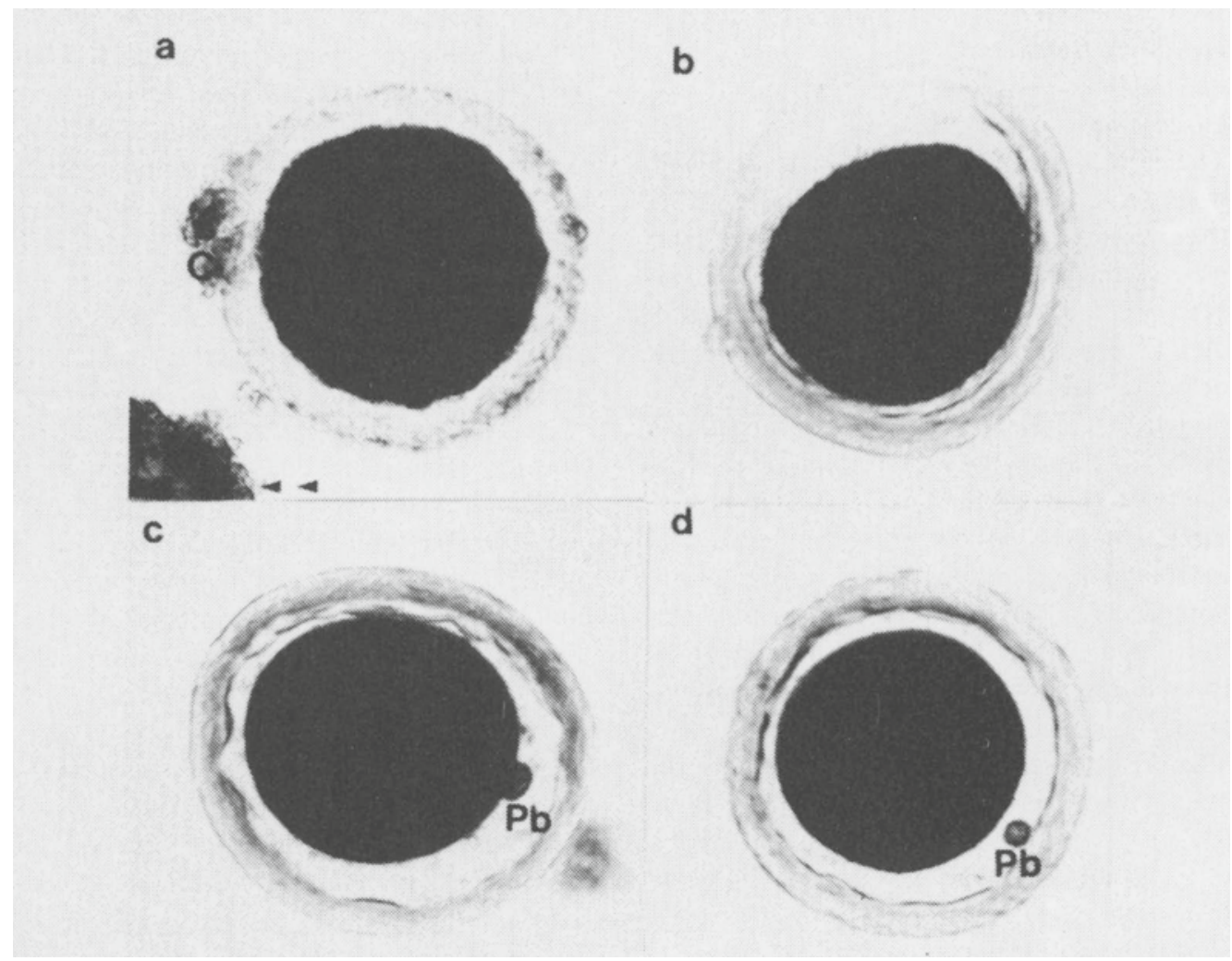

Figure 2. Oocyte maturation in the blue fox vixen. Light microscopic view of 4 freshly-collected oocytes in different stages of oocyte maturation (magnification $\times 100$ ).

a: Postovulatory tubal oocyte collected 2 days after the LH peak. The oocyte is partly denuded, but some cumulus cells $(\mathrm{C})$ are still associated with the zona pellucida.

$b$ : A completely denuded oocyte collected 3 days after the LH peak.

$c$ : An ovum in the process of extruding the first polar body $(\mathrm{Pb})$.

$d$ : An ovum where the first polar body $(\mathrm{Pb})$ is completely extruded. The ova in $\mathrm{c}$ and $\mathrm{d}$ were collected 4 days after the LH peak.

Fig. 2 shows a light microscopic view of 4 freshly-collected oocytes at different stages of oocyte maturation $(100 \times$ magnification $)$. The oocytes collected from preovulatory follicles were invested in an expanded multilayer of cumulus cells, and the oocyte nucleus was intact. The oocyte nucleus was broken down shortly after ovulation ( $\mathrm{LH}+$ 2). Within the next day the first polar body was extruded $(\mathrm{LH}+3)$, although in a few oocytes the polar body was not observed on day $\mathrm{LH}+3$. The cumulus cell mass detached from most ova after formation of the polar body. Ultrastructural studies showed that disconnection of gap junctions between cumulus cell projections and the oolemma occurred simultaneously with the breakdown of the oocyte nucleus.

Many oviductal ova showed signs of degeneration 4 to 5 days after the LH peak, and 
some collected 6 or more days after the LH peak were fragmented.

\section{Discussion}

The clinical and endocrine events associated with pro-oestrus, oestrus and ovulation in the present material largely follow the pattern outlined by Moller et al. (1984). However, we found that the maximum oestradiol-17 $\beta$ peak occurred on average 1 day before the LH peak, whereas Moller et al. reported that these 2 events occur simultaneously. In the dog, the oestradiol-17 $\beta$ peak has been reported to occur 1-2 days before the LH peak (Chakraborty 1987). This discrepancy may be due either to the small number of vixens in the 2 studies, thus expressing a normal range of variation, or to the relatively infrequent blood sampling regimes.

The FSH pattern found in this material closely resembles that described for the bitch (Olson et al. 1982). In the fox, plasma FSH concentrations have only previously been measured in males, where they increase shortly before onset of the mating season (a feature also characteristic for the vixens in this study). In periods with high androgen release, FSH concentrations have been shown to decrease in males, and a negative feedback mechanism for FSH similar to that for LH regulation has been proposed (Mondain-Monval et al. 1988). The obvious decline of FSH concentrations in pro-oestrus among all but 1 vixen in the present study indicates a possible modification of the levels due to increased levels of either oestrogen and/or androgens, since both testosterone and androstenedione levels are relatively high in female foxes in pro-oestrus ( $\mathrm{Mol}$ ler et al. 1984). In addition, an inhibitory effect of follicular inhibin-like substances on FSH may be involved, as described in the human and a variety of domestic animals
(Hiller et al. 1987, Leversha et al. 1987). Although the presence of inhibin in the follicles of the fox has not been investigated, lack of follicular inhibin production may explain why the vixen with inactive ovaries had continuously high FSH concentrations. Ovulation was confirmed in 7 of the 8 vixens with ovarian activity which were euthanised after day $\mathrm{LH}+2$. This corresponds to data obtained from the bitch in which the majority of ovulations take place 24-72 h after the LH peak (Wildt et al. 1978).

Oocyte nucleus breakdown was not initiated until after ovulation, and within the next 2 days the first polar body was extruded in most cases. This suggests that the period of final oocyte maturation is shorter in the fox than in the dog, in which postovulatory maturation of up to 3 days is needed (Holst \& Phemister 1971).

The role of the cumulus cells in postovulatory maturation has not been studied in the fox. In cattle, the disconnection between the cumulus cell projections and the oocyte occurs simultaneously with the breakdown of the oocyte nucleus (Hyttel 1987). During the preovulatory in vivo maturation of the bovine oocyte these features occur 9-12 h after the LH peak, which is believed to initiate the final oocyte maturation (Hyttel et al.1986). In the fox, the same relationship between cumulus-oocyte disconnection and oocyte nucleus breakdown was detected, but in this species these events occurred approximately 3 days after the LH peak. Thus, in the fox a different relationship may exist between induction of final oocyte maturation and the occurrence of the preovulatory LH surge.

\section{Acknowledgements}

We gratefully acknowledge the excellent cooperation of the staff at The Research Farm for Furbearing Animals at Heggedal, Norway. we would 
also like to thank Miss Inger Madsen at the Department of Anatomy, Royal Veterinary and Agricultural University in Copenhagen for preparing the oocytes for electron microscopy and Patricia Simon at The Foundation for Hormonal Research, Fresnes, France, for skilfull technical assistance with the hormone assays.

\section{References}

Chakraborty PK: Reproductive hormone concentrations during estrus, pregnancy and pseudopregnancy in the Labrador bitch. Theriogenology 1987, 27, 827-837.

Hiller SG, Tsonis CG, Wickings EJ, Eidne KA: Inhibition of FSH-stimulated granulosa cell function by a synthetic fragment of the porcine inhibin \& subunit: Evidence for involvment of GnRH receptors. J. Endocr. 1987, 113, R3-R5.

Holst PA, Phemister RD: The prenatal development of the dog: Preimplantation events. Biol. Reprod. 1971, 5, 194-206.

Hyttel P, Callesen H, Greve T: Ultrastructural features of preovulatory oocyte maturation in superovulated cattle. J. reprod. Fert. 1986, 76, 645-656.

Hyttel P: Bovine cumulus-oocyte disconnection in vitro. Anat. Embryol. 1987, 176, 41-44.

Hyttel P, Madsen I: Rapid method to prepare mammalian oocytes and embryos for transmission electron microscopy. Acta Anat. 1987, 129, 12-14.

Leversha LJ, Robertson DM, de Vos FL, Morgan FJ, Hearn MTW, Wettenhals REH, Findlay $J K$, Burger $H G$, de Kretser DM: Isolation of inhibin from ovine follicular fluid. J. Endocr. 1987, 113, 213-221.

Mondain-Monval M, Dutourne B, Bonnin $M$, Canivenc $R$, Scholler $R$ : Ovarian activity during the anoestrus and the reproductive season of the red fox (Vulpes vulpes L.). J. Steroid. Biochem. 1977, 8, 761-769.

Mondain-Monval M, Bonnin M, Canivenc $R$, Scholler $R$ : Heterologous radioimmunoassay for fox LH. Levels of LH during the reproductive season and the anoestrus in the red fox (Vulpes vulpes L.). Gen. Comp. Endocr. 1984, 55, 125-132.
Mondain-Monval M, Smith AJ, Simon P, Moller $O M$, Scholler R, Mc Neilly AS: Effect of melatonin implantation on the seasonal variation of FSH secretion in the male blue fox (Alopex lagopus). J. Reprod. Fert. 1988, 83, 345-354. Moller OM, Mondain-Monval M, Smith AJ, Metzger E, Scholler R: Temporal relationships between hormonal concentrations and the electrical resistance of the vaginal tract of the foxes (Alopex lagopus) at pro-oestrus and oestrus. J. Reprod. Fert. 1984, 70, 15-24.

Olson PN, Bowen RA, Behrendt MD, Olson JD, Nett TM: Concentrations of reproductive hormones in canine serum throughout late anoestrus, prooestrus and estrus. Reprod. 1982, 27, 1196-1206.

Pearson $O P$, Enders RK: Ovulation, maturation and fertilization in the fox. Anat. Rec. 1943, $85,69-81$.

Staigmiller RB, Moor RM: Effect of follicle cells on the maturation and developmental competence of ovine oocytes maturated outside the follicle. Gamete Res. 1984, 9, 221-229.

Wildt DE, Chakraborty PK, Panko WB, Seager $S W J$ : Relationship of reproductive behavior, serum luteinizing hormone and time of ovulation in the bitch. Biol. Reprod. 1978, 19, 561570.

\section{Sammendrag}

Endokrinologi og oocytmodning omkring ovulasjonen hos uparede eldre blårevtisper (Alopex lagopus).

Hos 9 av 10 eldre blårevtisper i spontan østrus skjedde ovulasjonen ca. 2 døgn etter den preovulatoriske frisetning av luteiniserende hormon (LH). Det ble observert en stigning i follikkelstimulerende hormon og progesteron i plasma samtidig med den preovulatoriske stigning i LH. Østradiol$17 \beta$ nådde sitt maksimum ca. 1 døgn før LH maksimum.

Hos den tiende revetispen ble det ikke observert en preovulatorisk LH-stigning. Det ble heller ikke observert follikler eller corpora lutea i ovariene 6 dager etter registrering av maksimal motstandsverdi.

Eggene ble ovulert som primære oocyter omgitt av en tykk cumulusmasse. Første meiotiske deling 
ble igangsatt innenfor 1 døgn etter ovulasjon, 2 døgn etter LH maksimum. Innenfor 2 døgn etter ovulasjon (3-4 dager etter LH maksimum) kunne første pollegeme observeres hos de fleste oocytter, og cumulusmassene var helt dissosiert fra zona pellucida.

Tidsintervallet mellom den preovulatoriske LH- frisetning og igangsettingen av den endelige oocyttmodning er dermed betydelig lengre hos denne arten enn f. eks. hos ku (ca. 48-72 t mot 9-12 t). Dette kan tyde på at sammenhengen mellom disse begivenhetene er noe annerledes hos blårev.

(Received June 7, 1988; accepted October 31, 1988).

Reprints may be requested from: W. Farstad, Dept. of Reproduction and Forensic Medicine, Norwegian College of Veterinary Medicine, P. O. Box 8146 Dep., N-0033 Oslo 1, Norway. 
